\title{
ANALISIS FAKTOR-FAKTOR YANG MEMPENGARUHI KUALITAS INFORMASI LAPORAN KEUANGAN PEMERINTAH DAERAH (Studi Empiris Pada SKPD Pemerintah Kabupaten Kepulauan Talaud)
}

\author{
Sintike Mentari Modo \\ David Paul Elia Saerang \\ Agus Tony Poputra
}

(Email : sintikemodo88@gmail.com)

\begin{abstract}
The research was conducted on the basis of the gap between expectations and reality. Hope, by improving the quality of human resources and improvement of legislation in the field of financial management areas, generating financial reports quality information. In fact, the quality of financial reporting information in Talaud Islands District Government showed no significant developments. This is evidenced by the BPK opinion obtained by the Government of Talaud Islands during 2006 through 2015 that Gives Opinion, Unusual, and Fair With Exceptions. Opinion adopted by Talaud Islands raises the question of why the quality of financial reporting information local governments do not progress. Based on the research objective, this study can be categorized in the associative causal type. The location study performed in Talaud Islands District Government. Data used in this study are primary data. Data collection is done by distributing questionnaires to Financial Management (User Administration Budget and Finance Officer) on regional work units (SKPD ) in Talaud Islands District Government. The population used was the financial manager in each SKPD, used as a sample 146 respondents. Data were analyzed using multiple linear regression analysis. The results showed that the Internal Monitoring, Understanding Regulation, Capacity Human Resources (HR), Use of Information Technology, and Organizational Commitment together have a significant effect on the Information Quality Local Government Finance Report (LKPD ), but the partial test results shows that only the Internal Control, Capacity Human Resources ( HR) Organizational commitment has a positive and significant impact on Quality of Information in Local Government Finance Report ( LKPD) .

Keywords: Internal Control, Understanding Regulation, Capacity Human Resources, Use of Information Technology, Organizational Commitment, Quality of information in Local Government Financial Report.
\end{abstract}

\subsection{Latar Belakang}

\section{PENDAHULUAN}

Fenomena perkembangan pemerintahan di Indonesia saat ini adalah tuntutan akuntabilitas terhadap pemerintah baik di pusat maupun daerah. Tuntutan akuntabilitas sektor publik terkait dengan perlu dilakukannya transparansi dan pemberian informasi kepada publik dalam rangka pemenuhan hak-hak publik. Akuntabilitas keuangan adalah pemberian informasi atas aktivitas dalam menjaga keakuratan laporan keuangan kepada pihak-pihak yang berkepentingan. Pemerintah baik pusat maupun daerah, harus dapat menjadi subyek pemberi informasi dalam rangka pemenuhan hak-hak publik yaitu hak untuk tahu (right to know), hak untuk diberi informasi (right to be informed) dan hak untuk didengar aspirasinya (right to be heard and to be listened to) (Mardiasmo, 2009). Oleh karena itu, pemerintah wajib merespon tuntutan akuntabilitas tersebut di atas.

Laporan keuangan pemerintah dapat memenuhi kualitas yang dikehendaki haruslah memiliki keempat karakteristik kualitatif diatas sebagai prasyarat normatif yang perlu diwujudkan dalam informasi akuntansi sehingga dapat memenuhi tujuannya. Kualitas laporan keuangan akan meningkatkan kualitas informasi yang disajikan dalam laporan keuangan. Para pengguna laporan keuangan yakin dalam mengambil keputusan karena didasarkan pada informasi yang telah 
dipersiapkan dengan baik, disetujui, dan diaudit secara transparan, dapat dipertanggungjawabkan dan berkualitas. Kualitas laporan keuangan adalah sejauh mana laporan keuangan menyajikan informasi yang benar dan jujur. Hal ini berarti bahwa kualitas laporan keuangan menunjukkan konsep kualitas informasi dari laporan tersebut.

Salah satu faktor utama yang dapat meningkatkan kualitas informasi laporan keuangan adalah pengawasan intern. Pengawasan intern merupakan salah satu bagian dari kegiatan pengendalian intern yang berfungsi melakukan penilaian independen atas pelaksanaan tugas dan fungsi Instansi Pemerintah (Djalil, 2014). Semakin maraknya kasus korupsi yang terjadi pada Pemerintah Kabupaten Kepulauan Talaud belakangan ini menunjukan indikasi bahwa pengawasan internal belum berfungsi secara baik. Tahap pengawasan, seharusnya merupakan proses kegiatan yang ditujukan untuk menjamin agar pemerintahan berjalan secara ekonomis, efisien dan efektif sesuai dengan rencana dan ketentuan peraturan perundang-undangan. Hal tersebut belum sepenuhnya berfungsi sebagaimana mestinya.

Faktor lain yang mempengaruhi kualitas informasi laporan keuangan adalah pemahaman tentang peraturan. Peraturan yang dimaksud adalah pedoman yang harus dilakukan serta prosedur terkait dengan serangkaian strategi untuk mencapai tujuan dalam hal ini Peraturan Pemerintah Nomor 71 Tahun 2010 tentang SAP yang berbasis akrual. Penerapan akuntansi berbasis akrual diperlukan untuk menghasilkan pengukuran kinerja yang lebih baik, serta untuk memfasilitasi manaje3men keuangan/aset yang lebih transparan dan akuntabel. Perubahan peraaturan tentang akuntansi pemerintah dari basis kas ke basis akrual cukup kompleks sehingga diperlukan pemahaman yang utuh mengenai konsep akuntansi.

Permasalahan penerapan basis akuntansi bukan sekedar masalah teknis akuntansi, yaitu bagaimana mencatat transaksi dan menyajikan laporan keuangan, namun yang lebih penting adalah bagaimana menentukan kebijakan akuntansi (accounting policy), perlakuan akuntansi untuk suatu transaksi (accounting treatment), pilihan akuntansi (accounting choice), dan mendesain atau menganalisis sistem akuntansi yang ada. Kebijakan untuk melakukan aktivitas tersebut tidak dapat dilakukan oleh orang (pegawai) yang tidak memiliki pengetahuan di bidang akuntansi (Forum Dosen Akuntansi Sektor Publik, 2006). Sehingga untuk dapat menghasilkan laporan keuangan yang berkualitas, maka kapasitas sumber daya manusia yang melaksanakan sistem akuntansi sangatlah penting.

Hal lain yang mempengaruhi kualitas informasi laporan keuangan adalah penggunaan teknologi informasi. Teknologi informasi sudah menjadi pilihan utama dalam menciptakan sistem informasi suatu organisasi yang tangguh dan mampu melahirkan keunggulan kompetitif ditengah persaingan yang semakin ketat ini. Dengan kemajuan teknologi pada saat sekarang, instansi-instansi pemerintah sudah mulai meninggalkan sistem manual, beralih ke sistem komputer. Namun yang menjadi kendala penerapan teknologi informasi antara lain berkaitan dengan kondisi perangkat keras, perangkat lunak yang digunakan, pemutakhiran data, kondisi sumber daya manusia yang ada, dan keterbatasan dana. Kendala ini yang mungkin menjadi faktor penggunaan teknologi informasi di instansi pemerintah belum optimal.

Hal lain yang mempengaruhi kualitas informasi laporan keuangan pemerintah daerah adalah komitmen organisasi. Komitmen dari Pemerintah Daerah dalam hal ini merupakan keinginan dari Satuan Kerja Perangkat Daerah (SKPD) untuk melakuan perubahan sesuai dengan adanya perubahan peraturan perundang-undangan. Adanya komitmen organisasi akan mempertahankan kepatuhan dalam penyajian laporan keuangan pemerintah yang reiable sesuai dengan standar akuntansi pemerintahan. Hal tersebut akan berdampak pada semakin baiknya kualitas dari informasi laporan keuangan. Pernyataan ini mendukung hasil penelitian Suwanda (2015), yaitu komitmen organisasi secara signifikan mempengaruhi Kualitas Laporan Keuangan Pemerintah Daerah.

Fenomena buruknya kualitas informasi laporan keuangan daerah memberikan peluang bagi adanya penyimpangan dan kekeliruan di bidang keuangan, terlihat dari banyaknya pejabat yang terjerat kasus hukum dan dapat menimbulkan kerugian negara/daerah. Administrasi keuangan yang buruk tersebut berlangsung terus menerus tentu saja rakyat akan menanggung akibatnya. Tatakelola keuangan yang buruk menyebabkan ekonomi biaya tinggi: pelayanan kepada publik yang 
buruk, tingkat kerusakan fasilitas publik yang lebih cepat dan biaya transaksi yang tinggi. Fenomena ini menimbulkan kesenjangan antara harapan dan kenyataan. Harapan, dengan peningkatan kualitas SDM dan perbaikan peraturan dibidang manajemen keuangan daerah, menghasilkan informasi laporan keuangan yang berkualitas. Kenyataannya, informasi kualitas laporan keuangan khususnya di Kabupaten Kepulauan Talaud tidak menunjukkan perkembangan yang signifikan, sebagaimana dikemukakan sebelumnya. Terjadinya kesenjangan menimbulkan pertanyaan tentang kualitas informasi laporan keuangan pemerintah daerah: mengapa kualitas informasi laporan keuangan pemerintah daerah di wilayah Kabupaten Kepulauan Talaud tidak mengalami perkembangan, apa yang menyebabkan, bagaimana menangulanginya?

\subsection{Rumusan Masalah}

Berdasarkan fenomena di atas, diangkat masalah penelitian yaitu pengembangan SDM meningkat dan reformasi peraturan juga semakin meningkat, namun kualitas informasi laporan keuangan masih belum memenuhi harapan. Masalah ini penting karena jawaban atas masalah ini akan memberikan petunjuk yang akan membantu pemda untuk merumuskan strategi peningkatan kualitas informasi laporan keuangan. Untuk merespon masalah ini, maka diperlukan penguatan dari pihak pengawas internal dan pengelola laporan keuangan. Untuk itu penelitian ini menganalisis kualitas informasi laporan keuangan pemerintah daerah. Penelitian serupa sebelumnya di wilayah Kabupaten Kepulauan Talaud belum pernah dilakukan. Berdasarkan latar belakang dan rumusan masalah yang telah diuraikan maka dapat dirumuskan pertanyaan penelitian sebagai berikut.

1. Apakah pengawasan internal berpengaruh terhadap kualitas informasi laporan keuangan pemerintah daerah pada Pemerintah Kabupaten Kepulauan Talaud?

2. Apakah pemahaman tentang peraturan berpengaruh terhadap kualitas informasi laporan keuangan pemerintah daerah pada Pemerintah Kabupaten Kepulauan Talaud?

3. Apakah kapasitas sumber daya manusia berpengaruh terhadap kualitas informasi laporan keuangan pemerintah daerah pada Pemerintah Kabupaten Kepulauan Talaud?

4. Apakah penggunaan teknologi informasi berpengaruh terhadap kualitas informasi laporan keuangan pemerintah daerah pada Pemerintah Kabupaten Kepulauan Talaud?

5. Apakah komitmen organisasi berpengaruh terhadap kualitas informasi laporan keuangan pemerintah daerah pada Pemerintah Kabupaten Kepulauan Talaud?

\subsection{Tujuan Penelitian} berikut.

Mengacu pada rumusan masalah penelitian di atas, maka penelitian ini bertujuan sebagai

1. Menganalisis pengaruh pengawasan internal terhadap kualitas informasi laporan keuangan pemerintah daerah pada Pemerintah Kabupaten Kepulauan Talaud.

2. Menganalisis pengaruh pemahaman tentang peraturan terhadap kualitas informasi laporan keuangan pemerintah daerah pada Pemerintah Kabupaten Kepulauan Talaud.

3. Menganalisis pengaruh kapasitas sumber daya manusia terhadap kualitas informasi laporan keuangan pemerintah daerah pada Pemerintah Kabupaten Kepulauan Talaud.

4. Menganalisis pengaruh penggunaan teknologi informasi terhadap kualitas informasi laporan keuangan pemerintah daerah pada Pemerintah Kabupaten Kepulauan Talaud.

5. Menganalisis pengaruh komitmen organisasi terhadap kualitas informasi laporan keuangan pemerintah daerah pada Pemerintah Kabupaten Kepulauan Talaud.

\subsection{Penelitian Terdahulu}

\section{TINJAUAN PUSTAKA}

Penelitian tentang hubungan antara kualitas jasa auditor internal dan kualitas informasi laporan keuangan. Nassir et al. (2001) meneliti efektivitas auditor internal dan kualitas informasi laporan keuangan pada perusahaan-perusahaan di Malaysia. Temuan penelitiannya menunjukkan bahwa keahlian personil, komitmen auditor internal, dukungan dari komite audit dan dewan direksi, kinerja audit dan integritas, efisiensi bagian audit, kompetensi dalam bidang audit, 
pengetahuan auditor intern tentang operasi perusahaan dan industri, independensi auditor internal merupakan atribut penting dalam meningkatkan kualitas auditor internal. Atribut-atribut tersebut memengaruhi secara positif efektivitas fungsi auditor intern terhadap peningkatan kualitas informasi dalam laporan keuangan.

Penelitian Gafarov (2009), disertasi tentang pengendalian intern dan kualitas pelaporan keuangan. Hal baru dari disertasi Gafarov 2009) adalah mengukur pelaporan keuangan dari karateristik kualitatif informasi akuntansi. Salah satu hasil yang ditujukkan dalam penelitiannya adalah implementasi pengendalian intern sangat penting terhadap pelaporan keuangan. Hasil penelitiannya menunjukkan bahwa pengendalian intern yang baik merupakan hal penting dalam pelaporan keuangan

Penelitian Van Beest et al. (2009) dilakukan pada 231 perusahaan terdaftar di pasar saham (AS, Inggris, dan Belanda) pada Tahun 2005 dan 2007. Melakukan penelitian faktor penentu kualitas pelaporan keuangan. Latar belakang penelitiannya didasarkan pertimbangan bahwa tujuan utama pelaporan keuangan adalah untuk menyediakan informasi pelaporan keuangan berkualitas tinggi (mengenai entitas ekonomi, terutama keuangan), berguna untuk pengambilan keputusan ekonomi. Temuan penelitiannya menunjukkan bahwa karakteristik kualitatif informasi akuntansi merupakan alat pengukuran yang valid dan dapat diandalkan untuk menilai kualitas informasi pelaporan.

Ratifah (2014) Penelitian ini menguji pengaruh sistem akuntansi keuangan daerah terhadap kualitas laporan keuangan dengan komitmen oranisasi sebagai variabel moderasi. Hasil studi empiris menunjukkan bahwa sistem akuntansi keuangan daerah memiliki pengaruh yang signifikan terhadap kualitas laporan keuangan. Begitu pula dengan menambahkan komitmen organisasi sebagai variabel moderasi, sistem akuntansi keuangan daerah memiliki pengaruh yang signifikan.

Suwanda (2015) Meneliti Faktor yang mempengaruhi Kualitas Laporan Keuangan Pemerintah Daerah untuk mendapatkan Opini Wajar Tanpa Pengecualian (WTP) dari Badan Pemeriksa Keuangan Republik Indonesia (BPK). Hasil analisis menunjukan bahwa penerapan SAP, Implementasi Sistem Pengendalian Internal, Komitmen Organisasi dan Pemanfaatan Teknologi Informasi secara signifikan mempengaruhi Kualitas Laporan Keuangan Pemerintah Daerah. Sementara Kualitas Sumber Daya Manusia, tidak berpengaruh secara terhadap Kualitas Laporan Keuangan Pemerintah Daerah.

\subsection{Landasan Teory}

\subsubsection{Teori keagenan (Agency Theory)}

Jensen dan Meckling (1976) menjelaskan hubungan keagenan sebagai berikut. "agency relationship as a contract under which one or more person (the principals) engage another person (the agent) to perform some service on their behalf which involves delegating some decision making authority to the agent". Artinya, hubungan keagenan merupakan suatu kontrak dimana satu orang atau lebih (prinsipal) memerintah orang lain (agen) untuk melakukan suatu jasa atas nama prinsipal serta memberi wewenang kepada agen untuk membuat keputusan yang terbaik bagi principal. Dalam pelaporan keuangan, pemerintah yang bertindak sebagai agen mempunyai kewajiban menyajikan informasi yang bermanfaat bagi para pengguna informasi keuangan pemerintah yang bertindak sebagai prinsipal dalam menilai akuntabilitas dan membuat keputusan baik keputusan ekonomi, sosial, maupun politik.

\subsubsection{Pengawasan Internal}

Peraturan Pemerintah Nomor 60 Tahun 2008 tentang Sistem Pengendalian Internal mendefinisikan Pengawasan Internal adalah seluruh proses kegiatan audit, reviu, evaluasi, pemantauan, dan kegiatan pengawasan lain terhadap penyelenggaraan tugas dan fungsi organisasi dalam rangka memberikan keyakinan yang memadai bahwa kegiatan telah dilaksanakan sesuai dengan tolok ukur yang telah ditetapkan secara efektif dan efisien untuk kepentingan pimpinan dalam mewujudkan tata kepemerintahan yang baik. Pengawasan internal merupakan salah satu 
bagian dari kegiatan pengendalian interen yang berfungsi melakukan penilaian independen atas pelaksanaan tugas dan fungsi Instansi Pemerintah.

Sebagai pengawas internal, Inspektorat Daerah yang bekerja dalam organisasi pemerintah daerah tugas pokoknya dalam arti yang lain adalah menentukan apakah kebijakan dan prosedur yang ditetapkan oleh manajemen puncak (Kepala Daerah) telah dipatuhi dan berjalan sesuai dengan rencana, menentukan baik atau tidaknya pemeliharaan terhadap kekayaan daerah, menentukan efisiensi dan efektivitas prosedur dan kegiatan pemerintah daerah, serta yang tidak kalah pentingnya adalah menentukan keandalan informasi yang dihasilkan oleh berbagai Unit/Satuan Kerja sebagai bagian yang integral dalam organisasi Pemerintah Daerah.

\subsubsection{Pemahaman Peraturan}

Pemahaman adalah proses, cara, perbuatan memahami atau memahamkan (Hoetomo, 2005). Pengertian Peraturan menurut kamus besar bahasa Indonesia adalah ketentuan yang mengikat warga kelompok masyarakat, dipakai sebagai panduan, tatanan, dan kendalikan tingkah laku yang sesuai dan diterima: setiap warga masyarakat harus menaati aturan yang berlaku, atau ukuran, kaidah yang dipakai sebagai tolok ukur untuk menilai atau membandingkan sesuatu. Definisi pemahaman peraturan adalah pemahaman anggota/pegawai mengenai peraturan, prosedur dan kebijakan tentang peraturan daerah (Kiranayanti, 2016). Peraturan yang di maksud disini adalah PP 71 Tahun 2010 tentang Standar Akuntansi Pemerintah Berbasis Akrual. Menurut Bastian (2006), Standar Akuntansi Pemerintahan, selanjutnya disebut SAP, adalah prinsip-prinsip akuntansi yang diterapkan dalam menyusun dan menyajikan laporan keuangan pemerintah. Dengan demikian SAP merupakan persyaratan yang mempunyai kekuatan hukum dalam upaya meningkatkan kualitas laporan keuangan pemerintah di Indonesia.

Para pengelola perlu memiliki pemahaman memadai tentang standar akuntansi keuangan daerah agar dapat menyajikan laporan keuangan yang handal. Dalam fungsi pengukuran, akuntansi melakukan proses pengumpulan, pencatatan realisasi pendapatan dan belanja serta transaksitransaksi yang terjadi diluar pendapatan dan belanja, serta aktivitas pelaporan. Selanjutnya akan dapat digunakan sebagai pengukur kinerja ekonomis, efisiensi, dan efektivitas pemerintah daerah.

\subsubsection{Kapasitas Sumber Daya Manusia}

Menurut Zuliatri (2012), Kapasitas sumber daya manusia adalah kemampuan seseorang atau individu, suatu organisasi (kelembagaan), atau suatu sistem untuk melaksanakan fungsi-fungsi atau kewenangannya untuk mencapai tujuannya secara efektif dan efisien. Kapasitas harus dilihat sebagai kemampuan untuk mencapai kinerja, untuk menghasilkan keluaran-keluaran (outputs) dan hasil-hasil (outcomes). Pemerintah daerah sangat membutuhkan sumber daya manusia yang professional dengan wawasan yang luas, memiliki kompetensi dibidangnya dan memiliki jiwa berkompetensi yang sportif. Sumber daya manusia yang professional akan mampu menyelesaikan tugas dan pekerjaannya secara tuntas, berdasarkan tugas pokok dan fungsinya. Sumber daya manusia yang berkualitas dan kompeten dalam bidang akuntansi (keuangan) menjadi penyangga utama untuk dapat tersusun laporan keuangan yang berkualitas.

\subsubsection{Penggunaan Teknologi Informasi}

Teknologi informasi adalah gabungan antara teknologi komputer dan teknologi telekomunikasi (Kadir dan Triwahwuni, 2013:2). Teknologi komputer adalah teknologi yang berhubungan dengan komputer, termasuk peralatan-peralatan yang berhubungan dengan komputer seperti printer, pembaca sidik jari, bahkan CD ROM, sedangkan teknologi telekomunikasi adalah teknologi yang berhubungan dengan komunikasi jarak jauh (Kadir dan Triwahwuni, 2013:3). Menurut Darmawan (2014:16), secara sederhana teknologi informasi dapat dikatakan sebagai ilmu yang diperlukan untuk mengelola informasi agar informasi tersebut dapat dicari dengan mudah dan akurat. Isi dari ilmu tersebut merupakan teknik-teknik dan prosedur untuk menyimpan informasi secara efisien dan efektif. 
Dalam Penjelasan Peraturan Pemerintah Nomor 65 Tahun 2010 tentang Sistem Informasi Keuangan disebutkan bahwa untuk menindaklanjuti terselenggaranya proses pembangunan yang sejalan dengan prinsip tata kelola pemerintahan yang baik (Good Governance), Pemerintah Pusat dan Pemerintah Daerah berkewajiban untuk mengembangkan dan memanfaatkan kemajuan teknologi informasi untuk meningkatkan kemampuan mengelola keuangan, dan menyalurkan informasi keuangan kepada pelayanan publik. Pemerintah perlu mengoptimalisasi pemanfaatan kemajuan teknologi informasi untuk membangun jaringan sistem informasi manajemen dan proses kerja yang memungkinkan pemerintahan bekerja secara terpadu dengan menyederhanakan akses antar unit kerja. Sistem informasi akuntansi berbasis komputer bertujuan untuk memperlancar arus informasi dan untuk memberikan kemudahan bagi para pengelola keuangan untuk menghasilkan informasi yang dapat dipercaya, relevan, tepat waktu, lengkap dan dapat dipahami.

\subsubsection{Komitmen Organisasi}

Komitmen Organisasi (Organization Commitment) adalah kemampuan dan kemauan untuk menyelaraskan perilaku pribadi dengan kebutuhan, prioritas dan sasaran organisasi. Pengukurannya meliputi: affective commitment, continuence commitment, normatif comitment (Allen dan Meyer, 1991 dikutip oleh Dunham, et al., 1994). Menurut Kalbers dan Forgati (1995) dikutip oleh Saerang dan Wokas (2011), komitmen organisasi cenderung didefinisikan sebagai suatu perpaduan antara sikap dan perilaku. Komitmen organisasi menyangkut tiga sikap yaitu, rasa mengidentifikasi dengan tujuan organisasi, rasa keterlibatan dengan tugas organisasi dan rasa kesetiaan kepada organisasi.

Pada konteks pemerintahan, aparat yang memiliki komitmen organisasi yang tinggi, akan menggunakan informasi yang dimiliki untuk menyusun laporan keuangan menjadi relatif lebih tepat. Dan dengan adanya komitmen organisasi yang tinggi akan mempertahankan kepatuhan dalam penyajian laporan keuangan pemerintah yang reliable sesuai dengan SAP.

\subsection{Kerangka Konseptual}

\section{KERANGKA KONSEPTUAL}

Pemerintah Daearah dituntut untuk lebih transparan dan akuntabel dalam mengelolah dan mempertanggungjawabkan uang maupun barang daerah. Bentuk laporan pertanggungjawaban atas pengelolaan keuangan daerah selama satu tahun anggaran adalah dalam bentuk laporan keuangan Pemerintah Daerah (LKPD). Laporan keuangan pemerintah daerah harus mengikuti Standar Akuntansi Pemerintahan sesuai Peraturan Pemerintah Nomor 71 Tahun 2010. Tujuan diberlakukannya hal tersebut adalah agar laporan keuangan lebih accountable dan semakin diperlukannya peningkatan kualitas laporan keuangan. Kualitas laporan keuangan pemerintah tidak terlepas dari peran pengawasan. Melalui pengawasan diharapkan dapat membantu melaksanakan kebijakan yang telah ditetapkan untuk mencapai tujuan yang telah direncanakan secara efektif dan efisien. Bahkan, melalui pengawasan tercipta suatu aktivitas yang berkaitan erat dengan penentuan atau evaluasi mengenai sejauhmana pelaksanaan kerja sudah dilaksanakan.

Laporan keuangan disajikan sesuai dengan SAP yang ditetapkan dengan Peraturan Pemerintah. SAP merupakan prinsip-prinsip akuntansi yang diterapkan sebagai pedoman dalam penyusunan laporan keuangan. SAP merupakan persyaratan dalam upaya meningkatkan kualitas LKPD. Penerapan SAP haruslah didukung dengan sistem yang baik dan dalam pelaksanaanya memerlukan SDM yang memiliki kompetensi di bidang akuntansi sehingga laporan keuangan yang disajikan dapat berkualitas tinggi. Dan Untuk memudahkan dalam penyusunan laporan keuangan akan lebih cepat dan akurat jika didukung dengan teknologi informasi yang ada.

Faktor-faktor yang dapat mempengaruhi kualitas laporan keuangan sehingga memiliki kriteria laporan yang berkualitas yaitu relevan, andal dapat dibandingkan, dan dapat dipahami, yang kemudian akan berdampak pada pemberian opini oleh BPK-RI diantaranya pengawasan internal, kapasitas SDM, pemahaman peraturan, pemanfaatan teknologi informasi dan komitmen organisasi. Kualitas Laporan Keuangan Pemerintah Daerah yang dihasilkan mencerminkan berhasil atau tidaknya suatu kinerja pemerintah daerah yang juga akan berguna sebagai informasi yang penting 
dalam pengambilan keputusan bagi pihak-pihak yang berkepentingan. Berdasarkan rumusan masalah, tujuan penelitian, dan landasan teori yang telah diuraikan dalam bab sebelumnya, maka diringkas kerangka konseptual sebagai deskripsi alur pemikiran yang melandasi penelitian ini diperlihatkan pada Gambar 3.1.

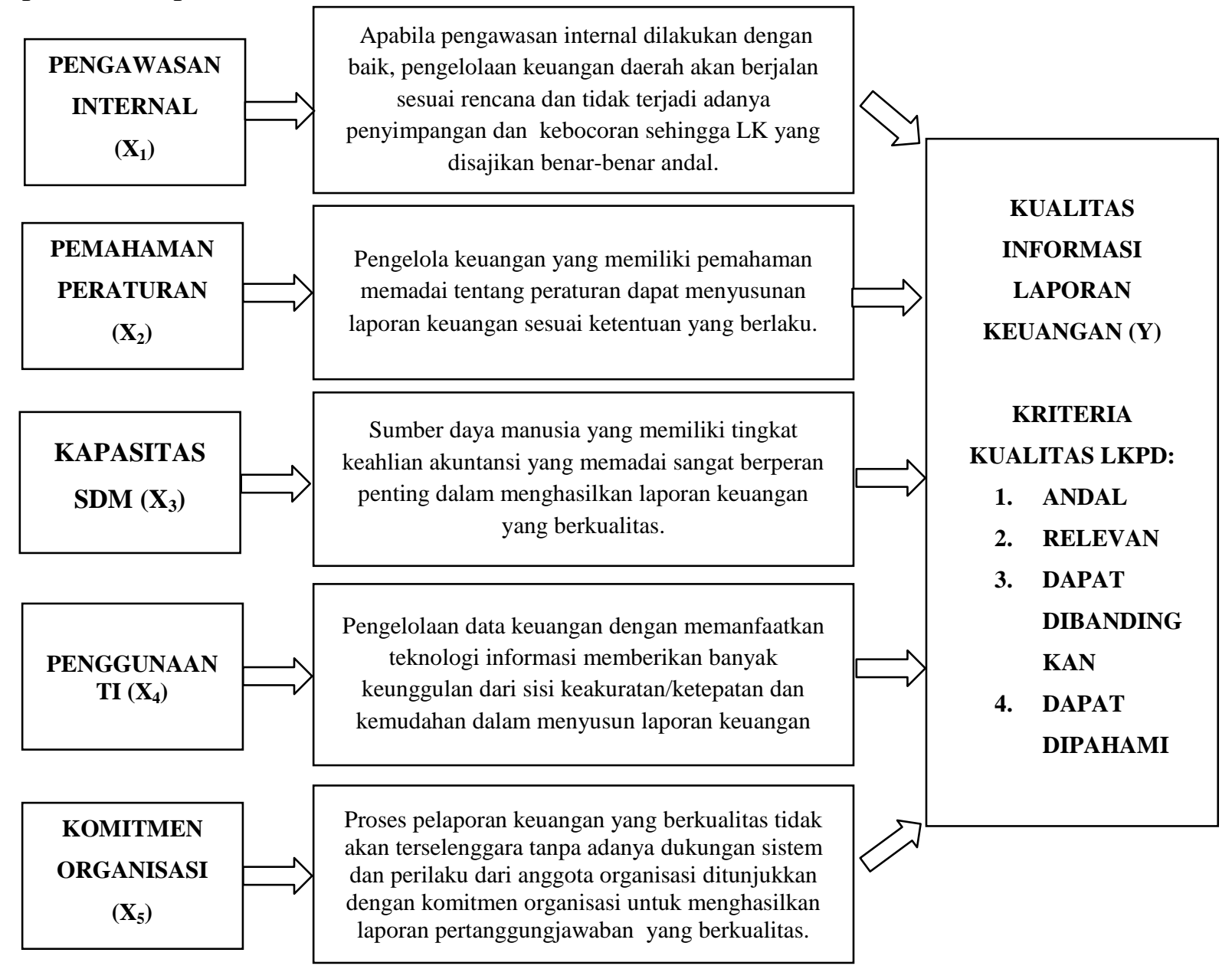

Gambar 3.1 Kerangka Konseptual Penelitian

\subsection{Hipotesis Penelitian}

Berdasarkan permasalahan yang telah dikemukakan sebelumnya dan kerangka konseptual tersebut diatas, maka dapat dirumuskan hipotesis sebagai berikut.

$\mathrm{H}_{1}$ : Pengawasan internal berpengaruh positif dan signifikan terhadap kualitas informasi laporan keuangan pemerintah daerah.

$\mathrm{H}_{1}$ : Pengawasan internal berpengaruh positif dan signifikan terhadap kualitas informasi laporan keuangan pemerintah daerah.

$\mathrm{H}_{3}$ : Kapasitas sumber daya manusia berpengaruh positifdan signifikan terhadap kualitas informasi laporan keuangan pemerintah daerah

$\mathrm{H}_{4}$ : Penggunaan Teknologi Informasi berpengaruh positif dan signifikan terhadap kualitas informasi laporan keuangan pemerintah daerah

$\mathrm{H}_{4}$ : Penggunaan Teknologi Informasi berpengaruh positif dan signifikan terhadap kualitas informasi laporan keuangan pemerintah daerah

\subsection{Jenis Penelitian yang Digunakan}

\section{METODE PENELITIAN}

Penelitian ini termasuk penelitian kuantitatif yang memiliki tingkat eksplanasi asosiatif yaitu penelitian yang didasarkan banyaknya obyek yang diteliti yang didesain secara spesifik untuk 
mengetahui obyek tertentu atau benar-benar fokus pada sampel yang telah ditentukan, sedangkan data yang digunakan adalah data primer melalui yaitu pembagian kuesioner.

\subsection{Populasi, Sampel, Besar Sampel, dan Teknik Pengambilan Sampel}

Populasi dalam penelitian ini adalah pegawai/staf pada 25 SKPD yang terdapat di Pemerintah Kabupaten Kepulauan Talaud. Teknik pengambilan sampel (sampling method) dilakukan secara bertujuan (purpossive sampling) dengan pertimbangan bahwa informasi berasal dari sumber yang sengaja dipilih berdasarkan kriteria yang telah ditetapkan peneliti (Sekaran, 2003 dikutip oleh Ponamon, 2014). Sampel yang diambil pada masing-masing SKPD sebanyak 5-15 orang sesuai dengan kriteria yang telah ditetapkan. Sehingga jumlah sampel keseluruhan sebanyak 146 sampel.

\subsection{Klasifikasi Variabel dan Definisi Operasional Variabel}

1. Pengawasan Internal $\left(\mathbf{X}_{1}\right)$, adalah pengawasan yang dilakukan oleh orang atau badan yang ada di dalam lingkungan unit organisasi yang bersangkutan.

2. Pemahaman Peraturan $\left(\mathbf{X}_{2}\right)$, Kiranayanti (2016) mendefinisikan pemahaman peraturan adalah pemahaman anggota/pegawai mengenai peraturan, prosedur dan kebijakan tentang peraturan daerah. Pemahaman Peraturan dalam variabel ini adalah pemahaman tentang SAP berbasis akrual.

3. Kapasitas Sumber Daya Manusia $\left(\mathbf{X}_{\mathbf{3}}\right)$, merupakan kemampuan baik dalam tingkat induvidu, organisasi/ kelembagaan, maupun sistem untuk melaksanakan fungsi-fungsi atau kewenangannya untuk mencapai tujuannya secara efektif dan efisien.

4. Penggunaan Teknologi Informasi $\left(\mathbf{X}_{\mathbf{4}}\right)$, merupakan penggunaan secara optimal dari komputer (mainframe, mini, micro), perangkat lunak (software), database, jaringan (internet, intranet), electronic commerce, dan jenis lainnya yangberhubungan dengan teknologi Wilkinson et.al, (2000) dikutip oleh Harfah (2012).

5. Komitmen Organisasi $\left(\mathbf{X}_{\mathbf{5}}\right)$, adalah kemampuan dan kemauan untuk menyelaraskan perilaku pribadi dengan kebutuhan, prioritas, dan sasaran organisasi. Komitmen organisasi yang rendah akan membuat individu untuk berbuat untuk kepentingan pribadinya.

6. Kualitas Informasi Laporan Keuangan (Y), variabel kualitas informasi laporan keuangan yang dimaksud dalam penelitian ini adalah taraf (mutu) atau terpenuhinya kriteria atau harapan yang melekat pada informasi laporan keuangan (Wilkinson, 2000:18). Kriteria yang dipakai untuk mengukur kualitas informasi laporan keuangan adalah dimensi relevan, andal, dapat diperbandingkan dan dapat dipahami (Peraturan Pemerintah Nomor 71 Tahun 2010, Bodnar (2003), GASB No. 1, SFAC No. 2 dan 8).

\subsection{Hasil Penelitian}

\section{ANALISIS DAN PEMBAHASAN HASIL PENELITIAN}

\subsubsection{Uji Asumsi Klasik}

Uji Normalitas, bertujuan untuk menguji apakah dalam model regresi, variabel terikat dengan variabel bebas keduanya mempunyai distribusi normal atau tidak. Penelitian ini menghasilkan koefisien Kolmogorov-Smirnov Z sebesar 0.200 dengan signifikan 0.600 Nilai signifikansi lebih besar dari alpha $(\alpha=0,05)$ maka dapat diinterpretasikan bahwa model uji telah memenuhi asumsi normalitas.

Uji Multikolinearitas, digunakan untuk mengetahui apakah terjadi korelasi yang kuat di antara variabel-variabel independen yang diikutsertakan dalam pembentukan model. Berdasarkan hasil coefficients yang terdapat pada Tabel 5.20 diketahui bahwa nilai tolerance dari masing-masing variabel independen di atas 0,1 dan nilai VIF dari masing-masing variabel independen lebih kecil dari pada 10, yaitu nilai VIF untuk variabel Pengawasan Internal $\left(\mathrm{X}_{1}\right)$ adalah sebesar $1.725<10$ dan nilai tolerance $0,580>0,10$; nilai VIF untuk variabel pemahaman tentang peraturan $\left(\mathrm{X}_{2}\right)$ adalah sebesar $1.465<10$ dan nilai tolerance $0,683>0,10$; nilai VIF untuk variabel kapasitas sumber daya Manusia $\left(\mathrm{X}_{3}\right)$ adalah sebesar $1.482<10$ dan nilai tolerance $0,675>0,10$; nilai VIF untuk variabel 
penggunaan teknologi informasi $\left(\mathrm{X}_{4}\right)$ adalah sebesar $1.418<10$ dan nilai tolerance $0,705>0,10$; nilai VIF untuk variabel komitmen organisasi $\left(\mathrm{X}_{5}\right)$ adalah sebesar $1.130<10$ dan nilai tolerance 0,885 > 0,10. Dengan demikian dapat disimpulkan bahwa tidak terjadi gejala multikolinearitas antara variabel Pengawasan Internal, pemahaman tentang peraturan, kapasitas sumber daya manusia, penggunaan teknologi informasi, dan komitmen organisasi dalam model penelitian ini.

Uji heteroskedastisitas, menggunakan uji Glesjer. Jika probabilitas signifikansi masingmasing variabel independen $>0,05$, maka dapat disimpulkan tidak terjadi heteroskedastisitas dalam model regresi (Ghozali, 2006). Uji heteroskedastisitas menghasilkan nilai signifikansi masingmasing variabel lebih besar dari 0,05 yang berarti bahwa secara statistik berarti variable tidak berpengaruh secara signifikan statistik karena $p$-value lebih besar dari 0,05 .

\subsubsection{Uji Hipotesis}

Uji Model Fit (Uji F), uji ini dilakukan untuk mengetahui apakah variabel independen yaitu Pengawasan Internal $\left(\mathrm{X}_{1}\right)$, Pemahaman tentang Peraturan $\left(\mathrm{X}_{2}\right)$, Kapasitas Sumber Daya Manusia $\left(\mathrm{X}_{3}\right)$, Penggunaan Teknologi Informasi $\left(\mathrm{X}_{4}\right)$, dan Komitmen Organisasi $\left(\mathrm{X}_{5}\right)$ secara bersama-sama berpengaruh terhadap variabel dependen yaitu Kualitas Informasi Laporan Keuangan (Y). Berdasarkan pengujian nilai $p$-value pada kolom signifikan adalah 0,00 angka ini lebih kecil dari 0,05. Dengan demikian maka dapat disimpulkan bahwa $\mathrm{H}_{\mathrm{o}}$ ditolak dan $\mathrm{H}_{\mathrm{a}}$ diterima. Hal ini berarti, Pengawasan Internal $\left(\mathrm{X}_{1}\right)$, Pemahaman tentang Peraturan $\left(\mathrm{X}_{2}\right)$, Kapasitas Sumber Daya Manusia $\left(\mathrm{X}_{3}\right)$, Penggunaan Teknologi Informasi $\left(\mathrm{X}_{4}\right)$, dan Komitmen Organisasi $\left(\mathrm{X}_{5}\right)$ secara bersama-sama berpengaruh terhadap variabel dependen yaitu Kualitas Informasi Laporan Keuangan (Y).

Uji t, Penggunaan regresi linier berganda dalam uji t memberikan hasil yang bila dimasukkan ke dalam persamaan penelitian menjadi:

$$
\begin{aligned}
& Y=\alpha+\beta_{1} X_{1}+\beta_{2} X_{2}+\beta_{3} X_{3}+\beta_{4} X_{4}+\beta_{5} X_{5}+\varepsilon \\
& Y=1.446+0,167 X_{1}+0,099 X_{2}+0,336 X_{3}-0,061 X_{4}+0,351 X_{5}+\varepsilon
\end{aligned}
$$

Nilai dari variabel Pengawasan Internal atau $b_{1}$ adalah $(0,167)$. Nilai koefisien regresi $b_{1}$ ini menunjukkan bahwa variabel Pengawasan Internal mempunyai pengaruh positif atau searah terhadap variabel Kualitas Informasi Laporan Keuangan. Dan hasil pengujian atas $\mathrm{t}$ statistik menunjukan nilai $p$-value variable $\mathrm{X}_{1}$ adalah 0,00 lebih kecil dari 0,05 dengan demikian $\mathrm{H}_{1}$ diterima atau dengan kata lain variabel Pengawasan Internal $\left(\mathrm{X}_{1}\right)$ berpengaruh positif dan signifikan secara statistik terhadap Kualitas Informasi Laporan Keuangan (Y) pada SKPD Pemerintah Kabupaten Kepulauan Talaud.

Nilai variabel Pemahaman tentang Peraturan atau $b_{2}$ adalah $(0,099)$. Nilai koefisien regresi $b_{2}$ ini menunjukkan bahwa variabel Pemahaman tentang Peraturan mempunyai pengaruh positif atau searah terhadap variabel Kualitas Informasi Laporan Keuangan. Dan hasil pengujian atas $\mathrm{t}$ statistik menunjukan nilai $p$-value variable $\mathrm{X}_{2}$ adalah 0,122 lebih besar dari 0,05, dengan demikian $\mathrm{H}_{2}$ ditolak atau dengan kata lain variabel Pemahaman tentang Peraturan $\left(\mathrm{X}_{2}\right)$ berpengaruh negatif dan tidak signifikan secara statistik terhadap Kualitas Informasi Laporan Keuangan pada SKPD Pemerintah Kabupaten Kepulauan Talaud.

Nilai dari variabel Kapasitas Sumber Daya Manusia atau $b_{3}$ adalah $(0,336)$. Nilai koefisien regresi $b_{3}$ ini menunjukkan bahwa variabel Kapasitas Sumber Daya Manusia mempunyai pengaruh positif atau searah terhadap variabel Kualitas Informasi Laporan Keuangan. Dan hasil pengujian atas $\mathrm{t}$ statistik menunjukan nilai $p$-value variable $\mathrm{X}_{1}$ adalah 0,00 lebih kecil dari 0,05 dengan demikian $\mathrm{H}_{3}$ diterima atau dengan kata lain variabel Kapasitas Sumber Daya Manusia $\left(\mathrm{X}_{3}\right)$ berpengaruh positif dan signifikan secara statistik terhadap Kualitas Informasi Laporan Keuangan pada SKPD Pemerintah Kabupaten Kepulauan Talaud.

Nilai variabel Penggunaan Teknologi Informasi atau $b_{4}$ adalah $(-0,061)$. Nilai koefisien regresi $b_{4}$ ini menunjukkan bahwa variabel Penggunaan Teknologi Informasi mempunyai pengaruh negatif atau tidak searah terhadap Kualitas Informasi Laporan Keuangan. Dan hasil pengujian atas $\mathrm{t}$ statistik menunjukan nilai $p$-value variable $\mathrm{X}_{4}$ adalah 0,479 lebih besar dari 0,05, dengan demikian $\mathrm{H}_{4}$ ditolak atau dengan kata lain variabel Penggunaan Teknologi Informasi $\left(\mathrm{X}_{4}\right)$ berpengaruh 
negatif dan tidak signifikan secara statistik terhadap Kualitas Informasi Laporan Keuangan pada SKPD Pemerintah Kabupaten Kepulauan Talaud.

Nilai variabel Komitmen Organisasi atau $b_{5}$ adalah $(0,336)$. Nilai koefisien regresi $b_{5}$ ini menunjukkan bahwa variabel Komitmen Organisasi mempunyai pengaruh positif atau searah terhadap variabel Kualitas Informasi Laporan Keuangan. Dan hasil pengujian atas $\mathrm{t}$ statistik menunjukan nilai $p$-value variable $\mathrm{X}_{5}$ adalah 0,013 lebih kecil dari 0,05 , dengan demikian $\mathrm{H}_{5}$ diterima atau dengan kata lain variabel Komitmen Organisasi $\left(\mathrm{X}_{5}\right)$ berpengaruh positif dan signifikan secara statistik terhadap Kualitas Informasi Laporan Keuangan pada SKPD Pemerintah Kabupaten Kepulauan Talaud.

Koefisien Determinasi $\left(\mathbf{R}^{2}\right)$ dan Korelasi (r), nilai koefisien determinasi atau $\mathbf{R}^{2}$ adalah sebesar 0,604 atau 60,4\%. Angka tersebut berarti sebesar 60,4\% Kualitas Informasi Laporan Keuangan pada SKPD Pemerintah Kabupaten Kepulauan Talaud dapat dijelaskan oleh variabel Pengawasan Internal $\left(\mathrm{X}_{1}\right)$, Pemahaman tentang Peraturan $\left(\mathrm{X}_{2}\right)$, Kapasitas Sumber Daya Manusia $\left(\mathrm{X}_{3}\right)$, Penggunaan Teknologi Informasi $\left(\mathrm{X}_{4}\right)$, dan Komitmen Organisasi $\left(\mathrm{X}_{5}\right)$. Sedangkan sisanya $(100 \%-60,4 \%=39,6 \%)$ disebabkan oleh faktor-faktor lain diluar pengujian ini.

Berdasarkan hasil tersebut maka disimpulkan variabel Pengawasan Internal $\left(\mathrm{X}_{1}\right)$, Pemahaman tentang Peraturan $\left(\mathrm{X}_{2}\right)$, Kapasitas Sumber Daya Manusia $\left(\mathrm{X}_{3}\right)$, Penggunaan Teknologi Informasi $\left(\mathrm{X}_{4}\right)$, dan Komitmen Organisasi $\left(\mathrm{X}_{5}\right)$ mempunyai korelasi positif dan sangat kuat terhadap variabel Kualitas Informasi Laporan Keuangan (Y), hal ini ditunjukkan dengan nilai koefisien korelasi sebesar 0,777 .

\subsection{Pembahasan}

\section{Pengaruh Pengawasan Internal Terhadap Kualitas Informasi Laporan Keuangan}

Hasil pengujian menunjukan bahwa variabel Pengawasan Internal berpengaruh positif dan signifikan secara statistik terhadap Kualitas Informasi Laporan Keuangan Pemerintah Daerah Kabupaten Kepulauan Talaud. Dengan demikian hipotesis 1 terdukung karena secara empirik terbukti.

Interpretasi dari temuan penelitian ini menunjukkan bahwa terdapat hubungan antara Pengawasan Internal dan Kualitas Informasi Laporan Keuangan pada Pemerintah Daerah Kabupaten Kepulauan Talaud. Hal ini menandakan bahwa Kualitas Informasi Laporan Keuangan didukung oleh Pengawasan Internal. Artinya Pengawasan Internal yang efektif mampu menunjang peningkatan Kualitas Informasi Laporan Keuangan, sekalipun belum optimal.

Beberapa hal peneliti temukan terkait dengan pengaruh Pengawasan Internal terhadap Kualitas Informasi Laporan Keuangan pada SKPD Pemerintah Daerah Kabupaten Kepulauan Talaud diuraikan pada penjelasan berikut.

1. Secara umum, pengawas intern memberikan respon yang positif terhadap kualitas informasi laporan keuangan. Pencapaian hasil ini diantaranya adalah sebagian besar responden menyatakan bahwa pengawas intern jujur atau obyektif dalam pelaksanaan tugasnya. Hasil ini konsisten dengan hasil yang ditunjukkan dalam jawaban responden atas kualitas informasi laporan keuangan, dimensi andal, indikator penyajian yang jujur, dan netral. Dimensi/indikator tersebut menunjukkan hasil yang cukup baik diantaranya pencatatan selalu dilakukan sesuai dengan substansi dan realitas ekonomis.

2. Lingkup kerja Pengawasan Internal memberikan respon yang positif terhadap peningkatan kualitas informasi laporan keuangan. Pencapaian hasil ini diantaranya adalah telaah terhadap informasi laporan keuangan telah dilakukan oleh auditor internal. Tujuannya, penentuan berbagai catatan yang mengandung informasi yang akurat, dapat dibuktikan keberadaannya, tepat waktu, lengkap, dan berguna untuk mendapatkan laporan yang berkualitas. Selain itu, Laporan Hasil Audit (LHA) selalu diterbitkan oleh auditor internal tidak lama setelah selesai audit, sehingga dapat digunakan sesuai kebutuhan.

3. Pelaksanaan pekerjaan Pengawasan Internal memberikan kontribusi positif terhadap kualitas informasi laporan keuangan. Hasil ini diantaranya ditandai dengan : (1) seluruh 
rencana telaah sering dijelaskan oleh auditor internal kepada audite sebelum pelaksanaan telaah dimulai, (2) penulisan/pencatatan program telaah sebagai pembuktian dalam pelaksanaan prosedur audit, penetapan tujuan audit, penetapan sifat, dan luas pengujian sering dilakukan oleh auditor internal, dan (3) kesimpulan dan rekomendasi sering didiskusikan dengan manajemen sebelum mengeluarkan laporan akhir.

4. Pengelolaan bagian pemeriksaan memberikan kontribusi positif terhadap kualitas informasi laporan keuangan. Pencapaian hasil ini diantaranya adalah pengelolaan bagian pemeriksaan telah dilakukan dengan baik oleh pimpinan auditor internal. Caranya dengan penyusunan berbagai kebijakan dan prosedur secara tertulis sebagai pedoman bagi staf auditor. Kebijakan dan prosedur tersebut meliputi: pedoman administrasi formal, teknik pemeriksaan/telaah, pengawasan terhadap staf. Kebijakan serta prosedur tersebut sesuai (tidak bertentangan) dengan peraturan. Pencapaian pengelolaan bagian pemeriksaan lainnya adalah tugas telaah telah diselesaikan dengan baik oleh sebagian besar auditor internal. Demikian juga dengan pengembangan SDM telah dilakukan oleh pimpinan auditor internal. Pengembangan tersebut berupa pemberian materi pelatihan sesuai dengan perkembangan dan tuntutan dalam pelaksanaan telaah laporan keuangan yang berkualitas. Hal lain yang mendukung pencapaian pengelolaan bagian pemeriksaan adalah koordinasi dengan auditor eksternal telah dilakukan oleh auditor internal. Caranya, dengan cukup terlibat dalam pemberian bantuan untuk percepatan audit laporan keuangan yang dilakukan oleh auditor eksternal.

Temuan ini sesuai dengan penelitian yang dilakukan oleh Nassir et al. (2001) yang meneliti efektivitas auditor internal dan informasi laporan keuangan pada perusahaan-perusahaan di Malaysia. Temuan penelitiannya menunjukkan bahwa keahlian, komitmen, dukungan dari komite audit dan dewan direksi, kinerja audit, efisiensi bagian audit, kompetensi, pengetahuan auditor intern tentang operasi perusahaan, dan independensi merupakan atribut penting dalam meningkatkan kualitas jasa auditor internal. Atribut tersebut memengaruhi secara positif peningkatan kualitas informasi dalam laporan keuangan. Identifikasi atribut tersebut sangat penting dapat membantu pengawas internal dalam melakukan evaluasi dan penilaian untuk menghasilkan informasi laporan keuangan yang berkualitas.

Fungsi tersebut di atas sejalan dengan tugas pengawas internal di lembaga pemerintahan. Tugas tersebut diatur dalam PP. No. 8 Tahun 2006 Pasal 33 ayat 3, Pasal 57; PP. No. 60 Tahun 2008, Instruksi Presiden RI No. 4 Tahun 2011 tentang Percepatan Peningkatan Akuntabilitas Keuangan negara point ke 4 bagian a. Peraturan tersebut menyatakan bahwa fungsi pemeriksaan intern adalah melakukan reviu atas laporan keuangan dan kinerja Pemerintah Daerah dalam rangka meyakinkan keandalan informasi yang disajikan sebelum disampaikan oleh kepala daerah kepada BPK. Dengan demikian pelaksanaan pengawasan internal yang baik dapat mendukung penyajian informasi laporan keuangan berkualitas. Pernyataan ini sesuai dengan pernyataan yang dikemukakan oleh Wriston et al. (1996:36). Menurutnya, laporan keuangan yang berkualitas dapat dihasilkan, jika mendapat dukungan dari manajemen, dewan komisaris, auditor internal, dan komite audit.

Secara umum hasil penelitian ini mengkonfirmasi asumsi filosofis dari teori agensi (agency theory), akuntabilitas publik dapat dimaknai dengan adanya kewajiban pihak pemegang amanah (agent) untuk memberikan pertanggungjawaban, menyajikan, melaporkan, dan mengungkapkan segala aktivitas dan kegiatan yang menjadi tanggungjawabnya kepada pihak pemberi amanah (principal) yang memiliki hak dan kewenangan untuk meminta pertanggungjawaban tersebut (Haryanto, Sahmuddin, Arifuddin, 2007). Demikian juga dengan pengawasan atas penyelenggaraan Pemerintah Daerah diharapkan untuk menjamin agar pelaksanaan kegiatan pemerintahan berjalan sesuai dengan rencana dan sesuai dengan peraturan perundang-undangan yang berlaku. Penilaian dan analisis dari pelaksanaan berbagai urusan pemerintahan di daerah dapat berjalan sesuai dengan standar dan kebijakan pemerintah yang berdasarkan peraturan Perundang-undangan dengan memberikan rekomendasi perbaikan-perbaikan yang perlu dilakukan terhadap pejabat yang berwenang (Ridla, 2013). 
Hasil rekapitulasi jawaban responden terhadap Pengawasan Internal secara umum menunjukkan nilai yang cukup tinggi mampu memengaruhi Kualitas Informasi Laporan Keuangan. Oleh karena itu, hasil penelitian ini dapat dijadikan dasar untuk menerapkan teori agensi di Pemerintah Daerah.

\section{Pengaruh Pemahaman Tentang Peraturan Terhadap Kualitas Informasi Laporan Keuangan}

Hasil pengujian menunjukan bahwa variabel Pemahaman tentang Peraturan berpengaruh negatif dan tidak signifikan secara statistik terhadap Kualitas Informasi Laporan Keuangan Pemerintah Daerah Kabupaten Kepulauan Talaud. Dengan demikian hipotesis 2 tidak terdukung karena secara empirik tidak terbukti.

Beberapa hal yang peneliti temukan terkait kurangnya pemahaman tentang peraturan disebabkan karena terjadi perubahan peraturan dalam waktu yang sangat singkat sehingga menyulitkan pejabat pengelola keuangan dalam memahami peraturan yang menjadi acuan di dalam penyusunan laporan. Berdasarkan jawaban responden dalam pertanyaan terbuka yang menjadi kendala dalam pemahaman peraturan tentang SAP berbasis akrual adalah keterbatasan sumber daya manusia (pendidikan staf yang tidak sesuai dan kurangnya pengalaman). Kurangnya pemahaman tentang SAP juga dikarenakan kurang efektifnya pelatihan dan bimtek untuk menyamakan persepsi terhadap pedoman yang digunakan sehingga pemahaman sumber daya manusia dimasing-masing SKPD berbeda tentang penerapan SAP berbasis akrual. Sumber daya manusia di bagian akuntansi/keuangan belum mendukung, masih sedikit pegawai bagian akuntansi/keuangan yang memiliki latar belakang pendidikan akuntansi dan hal ini terlihat dari data demografi responden.

Orang yang memiliki pemahaman akuntansi adalah orang yang pandai dan mengerti benar tentang akuntansi. Seseorang dikatakan paham terhadap akuntansi apabila orang tersebut mengerti dan pandai bagaimana proses akuntansi itu dilakukan sampai menjadi suatu laporan keuangan dengan berpedoman pada prinsip dan standar penyusunan laporan keuangan yang ditetapkan dalam peraturan perundang-undangan. Meskipun pemerintah daerah sudah memiliki software akuntansi, namun demikian karena penguasaan terhadap akuntansi masih belum memadai, maka kualitas laporan keuangan yang dihasilkan juga menjadi tidak memenuhi kaidah pelaporan keuangan normatif sesuai yang disyaratkan Standar Akuntansi Pemerintahan.

Dalam penelitian ini, diketahui bahwa secara parsial Pemahaman tentang Peraturan Keuangan $\left(\mathrm{X}_{2}\right)$ berpengaruh negatif dan tidak signifikan secara statistik terhadap Kualitas Informasi Laporan Keuangan (Y). Hal ini berarti bahwa pegawai bagian akuntansi/keuangan pada SKPD Pemerintah Kabupaten Kepulauan Talaud belum begitu memahami peraturan pemerintah tentang proses akuntansi sesuai Standar Akuntansi Pemerintah (SAP) sampai menjadi laporan keuangan sehingga tujuan untuk membuat laporan keuangan yang berkualitas belum tercapai.

Penelitian ini sejalan dengan penelitian Aidil (2010) yaitu Pemahaman tentang Peraturan tidak berpengaruh signifikan secara statistik terhadap kemampuan penyusunan laporan keuangan sehingga menimbulkan perbedaan penafsiran antara peraturan yang baru dan peraturan sebelumnya membuat para pegawai kesulitan dalam menyusun laporan keuangan.

\section{Pengaruh Kapasitas Sumber Daya Manusia Terhadap Kualitas Informasi Laporan Keuangan}

Hasil pengujian menunjukan bahwa variabel Kapasitas Sumber Daya Manusia berpengaruh positif dan signifikan secara statistik terhadap Kualitas Informasi Laporan Keuangan Pemerintah Daerah Kabupaten Kepulauan Talaud. Dengan demikian hipotesis 3 terdukung karena secara empirik terbukti.

Pencapaian hasil ini adalah pencapaian terhadap indikator pendidikan, pelatihan, dan pengalaman. Semakin baik tingkat pendidikan dan semakin sering mengikuti pelatihan pengelolaan keuangan daerah maka semakin baik laporan keuangan yang dihasilkan. Penyajian laporan keuangan pemerintah daerah lebih efektif disajikan dengan kualitas sumber daya manusia yang memiliki latar belakang pendidikan akuntansi. 
Penelitian ini mendukung penelitian Mahaputra dan Wayan Putra juga mengananalisis faktor-faktor yang mempengaruhi kualitas informasi pelaporan keuangan pemerintah daerah. Hasil uji hipotesis $H_{1}$ diketahui bahwa nilai $\beta 1=0,286$ dengan tingkat signifikansi t uji satu sisi sebesar 0,009 yang berarti dibawah nilai $\alpha=0,05$. Hal ini menunjukan bahwa variabel kapasitas sumber daya manusia berpengaruh positif dan signifikan pada kualitas informasi pelaporan keuangan. Karena sumber daya manusia merupakan pilar penyangga utama sekaligus penggerak roda organisasi dalam usaha mewujudkan visi dan misi serta tujuan dari organisasi tersebut.

Hasil penelitian ini menunjukan 30.1\% responden sangat setuju bahwa SDM yang berkualifikasi di Pemerintah Daerah Kabupaten Kepulauan Talaud dalam jumlah yang cukup. Artinya, SDM yang berkualifikasi belum merata di Pemerintah Daerah Kabupaten Kepulauan Talaud. Menurut peneliti, proses pengarahan terutama indikator pelatihan merupakan suatu proses untuk mengembangkan potensi staf Pemerintah Daerah agar memiliki kemampuan dan keterampilan yang lebih baik. Namun harus menjadi pemahaman Pemerintah Daerah untuk memberikan perlakuan yang adil dalam proses pembinaan termasuk dalam pemberian pendidikan yang memadai kepada staf.

Menurut peneliti, ketidakmerataan kompetensi yang dimiliki oleh SDM organisasi sedikit banyak akan menghambat efektivitas organisasi dalam mencapai tujuannya. Dalam struktur organisasi seperti saat ini, seluruh SDM yang ada harus memiliki kompetensi sama, sehingga tidak terdapat ketimpangan kompetensi dalam menjalankan tugas-tugas yang diberikan. Dengan demikian, pengarahan dalam hal ini pembinaan atau pendidikan mutlak dilakukan pada semua tingkatan tanpa mempertimbangkan sisi sosial, politik, ekonomi, budaya, dan lingkungan, serta agama. Tujuannya untuk mengurangi kesenjangan kompetensi SDM Pemerintah Daerah.

Dukungan pimpinan pada seluruh jenjang terhadap pentingnya kompetensi tidak hanya diperlihatkan pada ketersediaan, dan kecukupan anggaran pendidikan, serta pelatihan semata. Tetapi yang lebih penting adalah menciptakan suasana dan lingkungan yang kondusif bagi berkembangnya kompetensi secara mandiri, bahkan tidak berbiaya. Dibudayakannya forum-forum diskusi yang sifatnya informal, bahkan ketika rehat siang sekalipun. Cara tersebut, akan mempercepat proses pemerataan kompetensi diantara pegawai. Pegawai berkompetensi tinggi memberikan transfer knowledge tanpa diminta kepada sejawatnya yang masih belum memenuhi tingkat kompetensi yang ditentukan. Sebaliknya, pegawai yunior tidak segan bertanya kepada seniornya dan memiliki rasa ingin tahu yang besar terhadap sesuatu yang belum diketahuinya. Suasana belajar dan memberi pelajaran di antara anggota organisasi harus mendapatkan tempat yang layak dan harus didukung penuh oleh pimpinan Pemerintah Daerah.

\section{Pengaruh Penggunaan Teknologi Informasi Terhadap Kualitas Informasi Laporan Keuangan}

Hasil pengujian menunjukan bahwa variabel Penggunaan Teknologi Informasi berpengaruh negatif dan tidak signifikan secara statistik terhadap Kualitas Informasi Laporan Keuangan Pemerintah Daerah Kabupaten Kepulauan Talaud. Dengan demikian hipotesis 4 tidak terdukung karena secara empirik tidak terbukti.

Berdasarkan hasil rekapitulasi jawaban responden sebanyak 54 (47.8\%) responden menyatakan cukup untuk penggunaan jaringan internet di unit kerja. Dapat diketahui bahwa teknologi informasi selain sebagai teknologi komputer (hardware dan software) untuk pemrosesan dan penyimpanan informasi, juga berfungsi sebagai teknologi komunikasi untuk penyebaran informasi masih sangat terbatas. Belum semua SKPD memiliki tenaga operator komputer dan perangkat pendukung yang handal, berdasarkan rekapan pertanyaan terbuka di kuesioner yang menjadi kendala dalam penggunaan teknologi informasi pada umumnya adalah kurangnya brainware (sumber daya manusia) yang mempunyai kualitas yang memadai dalam mengelola teknologi informasi keuangan daerah baik dari pejabat (pengguna informasi) maupun staf (penyedia informasi) pemerintah daerah. Kendala lain adalah faktor keterbatasan dana dalam memenuhi kebutuhan akan sumber daya manusia yang berkualitas, perangkat keras yang belum memenuhi syarat teknis, serta perangkat lunak yang belum terintegrasi. Hambatan lainnya adalah kurangnya 
dukungan kebijakan atau kurang tegasnya komitmen dari atasan untuk mengembangkan teknologi informasi pengelolaan keuangan daerah. Hasil penelitian mengindikasikan belum maksimalnya upaya pemda dalam mengembangkan teknologi informasi pengelolaan keuangan daerah, terlihat dari belum dibuatnya kebijakan tentang: sistem dan prosedur aplikasi akuntansi keuangan; sistem dan prosedur penggunaan aplikasi kinerja; kebijakan tentang standar spesifikasi hardware teknologi informasi pemerintah daerah; dan keamanan (security) data/informasi keuangan daerah; serta jenis informasi keuangan daerah yang perlu dimuat dalam website.

Pengembangan teknologi informasi pengelolaan keuangan daerah perlu didukung dengan sarana dan prasarana yaitu brainware, hardware, dan software yang memadai, kebijakan tertulis maupun peraturan yang mewadahi satuan kerja yang bertanggung jawab penuh dalam pengelolaan data keuangan daerah secara elektronik. Pemerintah daerah hendaknya juga merancang sistem aplikasi komputer yang terintegrasi dalam pengelolaan keuangan daerahnya.

Ketidaksignifikanan ini juga disebabkan teknologi informasi yang tidak atau belum dimanfaatkan secara optimal, masih rendahnya kesadaran dalam memperbaharui (up-grade) aplikasi teknologi informasi (software) sesuai revisi terbaru Standar Akuntansi Pemerintahan (SAP) dan pengimplementasian teknologi informasi yang membutuhkan biaya yang tidak sedikit, sehingga implementasi teknologi informasi menjadi sia-sia dan semakin mahal dan tidak dapat mendukung penyajian laporan keuangan yang handal.

Secara umum hasil penelitian ini tidak sejalan dengan penjelasan Peraturan Pemerintah Nomor 65 Tahun 2010 tentang Sistem Informasi Keuangan Daerah disebutkan bahwa untuk menindak lanjuti terselenggaranya proses pembangunan yang sejalan dengan prinsip tata kelola pemerintahan yang baik (Good Governance), Pemerintah Pusat dan Pemerintah Daerah berkewajiban untuk mengembangkan dan memanfaatkan kemajuan teknologi informasi untuk meningkatkan kemampuan mengelola keuangan, dan menyalurkan informasi keuangan kepada pelayanan publik. Menurut peneliti pemerintah perlu mengoptimalisasi pemanfaatan kemajuan teknologi informasi untuk membangun jaringan sistem informasi manajemen dan proses kerja yang memungkinkan pemerintahan bekerja secara terpadu dengan menyederhanakan akses antar unit kerja.

Hasil penelitian ini tidak mendukung penelitian yang dilakukan oleh Indriasari (2008) dan Winidyaningrum (2010) yang menyatakan bahwa pemanfaatan teknologi informasi mempengaruhi nilai informasi pelaporan keuangan pemerintah daerah secara signifikan.

\section{Pengaruh Komitmen Organisasi Terhadap Kualitas Informasi Laporan Keuangan}

Hasil pengujian menunjukan bahwa variabel Komitmen Organisasi berpengaruh positif dan signifikan secara statistik terhadap Kualitas Informasi Laporan Keuangan Pemerintah Daerah Kabupaten Kepulauan Talaud. Dengan demikian hipotesis 5 terdukung karena secara empirik terbukti.

Interpretasi dari temuan penelitian ini menunjukkan bahwa terdapat hubungan antara Komitmen Organisasi dan Kualitas Informasi Laporan Keuangan pada S K PD Pemerintah Daerah Kabupaten Kepulauan Talaud. Hal ini menandakan bahwa Kualitas Informasi Laporan Keuangan didukung oleh Komitmen Organisasi. Artinya Komitmen Organisasi mampu menunjang peningkatan Kualitas Informasi Laporan Keuangan.

Berdasarkan hasil rekapitulasi jawaban responden dapat diketahui bahwa faktor yang meningkatkan komitmen organisasi adalah usaha keras untuk menyukseskan organisasi, kebanggaan bekerja pada organisasi tersebut, kesediaan menerima tugas demi organisasi, kesamaan nilai individu dengan nilai organisasi, kebanggaan menjadi bagian dari organisasi, organisasi merupakan inspirasi untuk melaksanakan tugas, anggapan bahwa organisasinya adalah organisasi yang terbaik, perhatian terhadap nasib organisasi.

Hasil penelitian ini mendukung penelitian yang dilakukan oleh Rosalin (2011) faktor-faktor yang mempengaruhi keandalan dan timeliness pelaporan keuangan dimana komitmen organisasi berpengaruh signifikan terhadap keandalan dan timeliness pelaporan keuangan. Karena komitmen organisasi mendorongan individu berbuat sesuatu untuk dapat meningkatkan keberhasilan 
organisasi sesuai dengan tujuan dengan lebih mengutamakan kepentingan organisasi dibandingkan dengan kepentingan individu.

\subsection{Kesimpulan}

\section{KESIMPULAN DAN SARAN}

1. Pengawasan Internal $\left(\mathrm{X}_{1}\right)$ berpengaruh positif dan signifikan secara statistik terhadap Kualitas Informasi Laporan Keuangan (Y). Hasil ini memberi indikasi bahwa kegiatan pengawasan internal telah dilakukan pada SKPD Pemerintah Kabupaten Kepulauan Talaud. Artinya pengawasan internal yang semakin baik akan meningkatkan kualitas informasi laporan keuangan sehingga tujuan untuk membuat laporan keuangan yang berkualitas dapat tercapai.

2. Pemahaman tentang Peraturan $\left(\mathrm{X}_{2}\right)$ berpengaruh negatif dan tidak signifikan secara statistik terhadap Kualitas Informasi Laporan Keuangan (Y). Hal ini disebabkan karena terjadi perubahan peraturan dalam waktu yang sangat singkat sehingga menyulitkan pejabat pengelola keuangan dalam memahami peraturan yang menjadi acuan di dalam penyusunan laporan. Selain itu, pegawai bagian akuntansi/keuangan pada SKPD Pemerintah Kabupaten Kepulauan Talaud belum begitu memahami proses akuntansi sampai menjadi laporan keuangan sehingga tujuan untuk membuat laporan keuangan yang berkualitas belum dapat tercapai.

3. Kapasitas Sumber Daya Manusia $\left(\mathrm{X}_{3}\right)$ berpengaruh positif dan signifikan secara statistik terhadap Kualitas Informasi Laporan Keuangan (Y). Hal ini disebabkan pembinaan yang dilakukan berupa pendidikan, pelatihan, penataran, atau sejenisnya khususnya bidang keuangan, terhadap sebagian staf Pemerintah Daerah seluruh pimpinan SKPD selalu dilibatkan dalam pengarahan untuk penyusunan informasi laporan.

4. Penggunaan Teknologi Informasi $\left(\mathrm{X}_{4}\right)$ berpengaruh negatif dan tidak signifikan secara statistik terhadap Kualitas Informasi Laporan Keuangan (Y). Hal ini disebabkan teknologi komputer (hardware dan software) untuk pemrosesan dan penyimpanan informasi, juga berfungsi sebagai teknologi komunikasi untuk penyebaran informasi masih sangat terbatas dan belum semua pegawai yang bekerja di bagian akuntansi/tata usaha keuangan pada SKPD Pemerintah Kabupaten Kepulauan Talaud mampu mengoperasikan Sistem Akuntansi Keuangan Daerah (SIMDA).

5. Komitmen Organisasi $\left(\mathrm{X}_{5}\right)$ berpengaruh positif dan signifikan secara statistik terhadap Kualitas Informasi Laporan Keuangan (Y). Hal ini disebabkan adanya usaha keras untuk menyukseskan organisasi, kebanggaan bekerja pada organisasi, kesediaan menerima tugas demi organisasi, kesamaan nilai individu dengan nilai organisasi, kebanggaan menjadi bagian dari organisasi, organisasi merupakan inspirasi untuk melaksanakan tugas, anggapan bahwa organisasinya adalah organisasi yang terbaik.

\subsection{Saran}

1. Berdasarkan hasil penelitian untuk variabel peran Pengawasan Internal sangat penting dalam hal peningkatan Kualitas Informasi LKPD, karena itu hendaknya peran pengawas internal dapat terus ditingkatkan. Perlu meningkatkan kemampuan professional auditor internal dengan bersertifikasi Jabatan Fungsional Auditor (JFA) agar dalam menjalankan tugasnya lebih efektif. Dengan efektifnya peran pengawas intern pada pemda akan meningkatkan kinerja pemeriksaan internal. Selain itu, dapat meningkatkan kualitas informasi laporan keuangan.

2. Pemerintah Kabupaten Kepulauan Talaud dalam penyusunan LKPD harus berpedoman pada SAP untuk menghindari penyimpangan-penyinpangan yang terjadi sehingga dapat memberikan informasi bagi pengguna laporan (masyarakat, para wakil rakyat, lembaga pengawas, lembaga pemeriksa, pihak yang berperan dalam proses donasi, investasi, pinjaman dan kreditor yang memerlukan informasi keuangan untuk menghitung resiko, likuiditas dan solvabilitas, Pemerintah dan para pembayar pajak) sebagai dasar pengambilan keputusan dan sebagai bahan evaluasi kinerja pemerintah setiap periode sehingga bermanfaat bagi kepentingan masyarakat. Pemerintah Kabupaten Kepulauan Talaud dalam 
hal ini pengawas intern untuk lebih mengoptimalkan dan berkelanjutan melalui pembinaan dan pengawasan penerapan SAP mulai dari perencanaan, pelaksanaan, dan pelaporan. Perlu sosialisasi yang lebih intensif setiap terjadi perubahan peraturan. Bila perlu membentuk lembaga teknis yang secara khusus yang bertugas membina pengembangan keuangan daerah di daerah.

3. Kapasitas SDM (Pengelola Keuangan) di masing-masing SKPD di Pemerintah Kabupaten Kabupaten Kepulauan Talaud memiliki pengaruh dalam menentukan Kualitas Informasi LKPD. Pemerintah Kabupaten Kabupaten Kepulauan Talaud melalui Badan Kepegawaian Daerah untuk pengelola keuangan SKPD perlu mengintensifkan pelatihan dan Bimtek yang manajemen keuangan dan akuntansi keuangan daerah secara berkelanjutan dan menyeluruh. Tujuannya, mempermudah proses penyajian informasi laporan keuangan yang berkualitas sehingga pemahaman terhadap peraturan dan standar penyusunan laporan keuangan lebih optimal dan dapat meningkatkan interaksi dengan sistem pengelola keuangan yang ada.

4. Pemerintah Kabupaten Kepulauan Talaud dalam upaya meningkatkan Kualitas Informasi LKPD yang dihasilkan selain Kapasitas SDM dan ketaatan terhadap peraturan perundangundangan, sarana prasarana pendukung baik dari segi kuantitas maupun kualitas juga harus memadai sehingga dapat mengikuti perkembangan teknologi informasi. Sistem Informasi Keuangan Daerah yang ada dapat mempermudah dalam pengelolaan keuangan mulai dari perencanaan, pelaksanaan serta dalam pelaporan. Tim Angaran Pemerintah Daerah Kabupaten Kepulauan Talaud dalam perencanaan anggaran supaya memprioritaskan anggaran pengadaan dan pemeliharaan rutin sarana prasarana penunjang seperti komputer, jaringan online dan jaringan internet pada SKPD sehingga mampu berinteraksi dengan SIMDA untuk menghasilkan data secara cepat, tepat dan akurat.

5. Untuk Peningkatan Kualitas Informasi Laporan Keuangan dapat dilakukan melalui :

a) memperbanyak tenaga ahli/konsultan di setiap bidang keuangan daerah. Selain itu, senantiasa melakukan kerja sama dengan perguruan tinggi. Kerjasama tersebut dapat berupa: (1) pengembangan SDM yang dimiliki pemda, (2) pengembangan dan penyusunan kebijakan akuntansi pemerintahan, dan (3) pengembangan indikator efektivitas pengendalian intern dan kualitas informasi laporan keuangan;

b) peran pihak media massa dan masyarakat. Pihak tersebut lebih peduli dengan kualitas informasi laporan keuangan pemda dengan meningkatkan derajat pengawasannya (lebih kritis) karena mencerminkan kedalaman pengawasan sebagai public control. Tujuannya, dapat berpartisipasi secara maksimal dalam mengawasi dan mendorong memenuhi harapan publik peningkatan akuntabilitas keuangan;

c) berdasarkan saran dalam point (b) di atas, maka pemerintah perlu memberi ruang yang jelas bagi masyarakat dan media massa dalam mengawasi dan mengakses setiap informasi dan kebijakan pemda. Tujuannya, masyarakat dan media massa dapat menyampaikan berbagai permasalahan yang terkait dengan kepentingan publik sekaligus menjadi media public control;

6. Komitmen dari pemda (manajemen dan pengawas internal) untuk perbaikan kualitas informasi laporan keuangan perlu ditingkatkan. Saat ini kualitas informasi laporan keuangan masih rendah, terlihat dari penyusunan laporan keuangan asal jadi. Laporan keuangan hanya dipakai sebagai media pertanggungjawaban pelaksanaan anggaran. Belum banyak dipakai sebagai dasar pengambilan keputusan. Misalnya pemberian insentif atau dasar bagi investor untuk pemberian modal bagi pembangunan infrastruktur daerah.

7. Untuk penelitian selanjutnya, supaya dapat mempertimbangkan atau menambahkan variabel-variabel lain yang diduga berpengaruh signifikan terhadap kualitas informasi laporan keuangan.

\section{DAFTAR PUSTAKA}

Aidil, 2010. Faktor-Faktor yang Mempengaruhi Kemampuan Penyusunan Laporan Keuangan Pemerintah Daerah ( Studi Empirriss pada Pemerintah Kota Tebing Tinggi), USU. Medan. 
Bastian, Indra. 2006, Akuntansi Sektor Publik, Suatu Penganta. Erlangga. Jakarta

Darmawan, Deni. 2012. Pendidikan Teknologi Informasi Dan Komunikasi. Bandung: PT. Remaja Rosdakarya.

Djalil, Rizal. 2014. Akuntabilitas Keuangan Daerah Implementasi Pasca Reformasi. Jakarta: RMBOOKS.

Forum Dosen Akuntansi Sektor Publik. 2006. Standar Akuntansi Pemerintahan: Telaah Kritis PP Nomor 24 Tahun 2004. Yogyakarta. BPFE.

Gafarov, T. 2009. Financial Reporting Quality Control for Internal Control Implementation. A. Disertasi For the award of Doctor of Philosophy, Business and Management Faculty Institude of Finances, Brno University of Tecnology.

Imam Ghozali, I. 2006. Aplikasi Analisis Multivariate dengan Program SPSS. Semarang: Badan Penerbit-UNDIP.

Harfan, H. 2012. Pengaruh Penggunaan Teknologi Informasi dan Keahlian Pemakai Terhadap Kualitas Informasi Akuntansi.

Jensen, M. C. and W. H. Meckling. 1976. Theory of Firm: Managerial Behaviour, Agency Cost \& Ownership Structure. Journal of Financial Economics. Oktober. (Vol.3): No. 4: 305-306

Kadir, A. dan T. Ch. Triwahyuni. 2013. Pengantar Teknologi Informasi Edisi Revisi. Yogyakarta: CV. Andi Offset.

Kiranayanti. 2016. Pengaruh Sumber Daya Manusia, Sistem Pengendalian Intern, Pemahaman Basis Akrual-Jurnal Akuntansi Universitas Udayana Vol.16.2. Agustus (2016): 1290-1318.

Mardiasmo. 2009. Akuntansi Sektor Publik. Yogyakarta: Andi Yogyakarta.

Nassir, A. et al., 2001. The Effectiveness of the internal Auditor in Malaysia Listed Firm. Journal of Malaiysia Institute of Accounting. (Vol. 14 (9)), p. 30-33.

Ponamon Irene Fransisca. 2014. Pengaruh Pengawasan Internal, Pemahaman Sistem Akuntansi Keuangan, dan Kapasitas Sumber Daya Manusia Terhadap Kualitas Informasi Laporan Keuangan Pemerintah pada SKPD Pemerintah Kota Manado.

Peraturan Pemerintah Nomor 60 Tahun 2008 tentang Sistem Pengawasan Internal Pemerintah.

Peraturan Pemerintah Nomor 65 Tahun 2010 tentang Sistem Informasi Keuangan Daerah.

Peraturan Pemerintah Nomor 71 Tahun 2010 tentang Standar Akuntansi Pemerintahan.

Ratifah, Ifa. 2014. Komitmen Organisasi Memoderasi Pengaruh Sistem Akuntansi Keuangan Daerah terhadap Kualitas Laporan Keuangan di Pemerintah Daerah Kabupaten Karawang.

Saerang, D. P. E. dan H. R. N. Wokas. 2011. Pengaruh Komitmen, dan Pendidikan Terhadap Kemampuan Penyusunan Laporan Keuangan SKPD Pemerintah Daerah Sulawesi Utara.

Suwanda D. 2015. Factors Affecting Quality of Local Government Financial Statements to Get Unqualified Opinion (WTP) of Audit Board of the Republic of Indonesia (BPK). Research Journal of Finance and Accounting (Paper) ISSN 2222-2847 (Online) (Vol.6): No.4.

Van Beest., G. Braam, and S. Boelens. 2009. Quality of Financial Reporting: Measuring Qualitative Characteristics. Nijmegen Center For Econoics (NiCE) Working Paper, Radboud University Nijmegen. http:/www.ru.nl/nice/workingpapers.

Winidyaningrum dan Rahmawati, 2010. Pengaruh Sumber Daya Manusia Dan Informasi Teknologi Pemanfaatan Kehandalan Dan Ketepatan Waktu Pelaporan Keuangan Pemerintah Daerah.

Wriston, K. D., Esposito, D. J., and Fox, J. L. 1996. How Objective Are Outside Auditor? Journal of Accountancy: Paris. Vol. 181 (2). P. 36-38.

Zuliarti, 2012. Pengaruh Kapasitas Sumber Daya Manusia, Pemanfaatan Teknologi Informasi, dan Pengendalian Intern Akuntansi Terhadap Nilai Informasi Pelaporan Keuangan Pemerintah Daerah Studi Pada Pemerintah Kabupaten Kudus. 